\title{
HALOTHANE (2-BROMO-1,1,1-TRIFLUORO-2-CHLOROETHANE) AS AN EXAMPLE IN THE DISCIPLINE "FORENSIC CHEMISTRY" FOR UKRAINIAN STUDENTS OF PHARMACY
}

\author{
Elena Welchinska ${ }^{1}$
}

\begin{abstract}
The quantity of pharmaceutical preparations, which are used in medicine and different areas of the economy increased because of the development of the chemical and pharmaceutical industries. These substances can caise poisonings in certain situations. The sources of poisonings are: sewage of industrial enterprises; pesticides (chemical poisons) for fighting agricultural pests; soil; vegetables and fruits; chemical substances for fights against rodents and insects. The use of chemical substances in the economy increases the quantity of poisons as objects of forensic toxicological analysis. "Forensic chemistry" - is a science which studies methods for the isolation, purification, qualitative analysis and quantitative analysis of toxic and poisonous substances and their metabolites in objects of various origins: animal and plant biological materials, industrial waste, emissions of waste water, the air of industrial enterprises, soil and agricultural crops, etc. The aim of this work is to study the importance of chemicals, namely fluorine-containing organic compounds, which are strong toxic substances, during the study of "Forensic Chemistry" throughout the academic period at the Pharmaceutical Faculty in Ukraine.
\end{abstract}

UDC Classification: 54.01, 615 (075); DOI: http://dx.doi.org/10.12955/cbup.v6.1316

Keywords: forensic chemistry, halothane, toxicity, poison.

\section{Introduction}

Forensic chemistry is of the vital importance in the diagnostics of poisonings and crime prevention activity. Conclusions of toxicological chemists on the presence and the amount of poison in the investigational material provide great support for forensic experts. The conclusions of toxicologists, chemists, hygienists and pharmacologists about the high toxicity of certain pharmaceutical products, in food and substances used in everyday life are the basis for deciding whether to remove these substances from public use, changes in storage conditions and availability of these substances.

The results obtained from chemical-toxicological and sanitary investigations of the air and industrial waste water containing toxic substances were used by sanitary protection authorities for the purpose of the construction or reconstruction of waste treatment facilities. These methods of forensic chemistry help to define and control the maximum permissible concentration (MPC) of toxic substances presents in water and air and develop standards of pesticide residues and other toxic substances in food according to Moffat et al. (2011), Bayerman (1987), Busari et al. (2009), Ellenhorn (2003), Knunyants et al. (1992), and Welchinska (2017). The strategic line of pharmaceutical graduates' preparing is a complex approach used for the studying of pharmaceutical chemistry and forensic chemistry courses together. Future professional activities of young pharmacists will be most successful in mastering the complex knowledge of both pharmaceutical and toxicological analysis (European Association for Quality Assurance in Higher Education, Helsinki, 2005, Communiqué of the Conference of European Ministers Responsible for Higher Education, 2010).

One of the most important groups of toxic substances being studied in forensic chemistry is the group of substances which are isolated from biological material through steam distillation at atmospheric pressure or through mineralization. These are the fluoro-containing organic compounds such as fluoroacetic acid, fluorouracil, fluocortolone, flunixin, flumetasone, halothane and others. Halothane (known as Fluothane, Rhodialothan, Phthorothanum) is a famous general inhalation anesthetic. Its boiling point is $49-51{ }^{\circ} \mathrm{C}$. It is considered as a volatile poison (VOC). The toxic dose of halothane is $200 \mathrm{mg} / \mathrm{L}$. Its concentration in blood $(7-310 \mathrm{mg} / \mathrm{L})$ has been associated with fatalities. Therefore, halothane is an important object for forensic analysis.

Each toxic substance of the class of volatile poisons is studied according to the following plan: the history of discovery, application in medicine and other fields, toxicological significance, symptoms of poisoning and first medical aid in poisoning, peculiarities of biotransformation, features of isolation from various objects, methods of qualitative and quantitative analysis.

Halothane was introduced into clinical use during 1956. It was hailed as a great advance in anesthesia. Its advantages of potency, general smoothness of administration led rapidly to widespread use. Reports of postoperative liver necrosis after the use of halothane began to appear from 1958. As Erskine et al.

\footnotetext{
${ }^{1}$ Pharmaceutical Faculty, Bohomolets National Medical University, Kyiv, Ukraine, elena_wwu@ukr.net
} 
(1990) mentioned, halothane inhibited the ability of human neutrophils to move towards the chemoattractant agent, casein. Symptoms of poisoning by halothane include an irregular heartbeat, respiratory depression, and liver problems (halothane hepatitis). The hepatitis syndrome had a mortality rate of $30 \%$ to $70 \%$. Halothane hepatitis is a result of the metabolism of halothane to trifluoroacetic acid by oxidation in the liver. In addition, the side effects of halothane include:, decreased oxygen in the tissues or blood, kidney damage, malignant hyperthermia, problems with circulation, yellowing of skin or eyes (jaundice). In case of over dose by non-inhalation, Halothane can cause swelling of lungs, stopping of the action of the right ventricle of the heart , development of liver necrosis. After intranasal oxygen introduction, normalization of the patient is possible. Halothane is rapidly absorbed upon inhalation. It accumulates in adipose tissue. Approximately $60-80 \%$ of an absorbed dose is exhaled unchanged from the lungs in $24 \mathrm{~h}$ and smaller amounts continue to be exhaled for several weeks. More liver enzyme abnormalities occurred after multiple exposures to halothane than after non-halothane anesthesia.

\section{Methods}

The main principles and requirements for the accreditation of a university graduate in the specialty "Pharmacy" in the conditions of the Bologna system in Ukraine and in accordance with the quality assurance guidelines (ENQA) (project 562013-EPP-1-2015-1-PL-EPPKA2-CBHE -SP, 2015 ) are the following: compliance with professional competencies; high-level specialization; the number of graduates should be provided with jobs; a high level of trust in the profession of "pharmacist", allowing graduates to choose this profession after school; the level of the material and technical base of the university; information support.

The main methods used during the studies are pedagogical, psychological, statistical, chemical, analytical, biochemical ones. Basic topics which are tested contain questions related to the general characteristics of poisons: the objects of study, the methods of isolating the studied material, general regularities of toxic dynamics and toxic kinetics, general methods of qualitative detection and quantitative definition, the scheme of metabolism on the phase's I and II. When studying the discipline "Forensic Chemistry" students master the knowledge of chemical, analytical, biochemical methods of studying toxic substances; statistical methods are used to understand the results of such studies; the teacher in the process of work applies pedagogical, psychological approaches to optimize the learning process.

\section{Results and Discussions}

It should be noted that these reactions were not presented schematic in the literature. In the academic literature (Welchinska, 2017) for students of the medical university, it describes the qualitative detection and quantification of the processes of metabolism and reaction in the form of the proposed schemes by the authors. Particular attention is paid to the study of chemical transformations in the metabolism of a poisonous substance, chemical reactions of a qualitative analysis of this compound, and methods for its quantitative determination.

Metabolism of halothane takes place in the following main ways: 1) 60-80\% of an absorbed dose is exhaled unchanged from the lungs; 2) debromination; 3) dechlorination; 4) replacement of fluorine atom with an $\mathrm{CH}_{3} \mathrm{O}$ - group, conjugation of the metabolite with glucuronic acid; 5) metabolites which detected in expired air and in blood: 2-chloro-1,1,1-trifluoroethane (CTF), 2-chloro-1,1difluoroethylene (CDF); 6) excretion with urine: trifluoroacetic acid (TFAA) and its salts, bromide ions (Scheme I).

The main reactions of halothane's biotransformation include reduction to 2-chloro-1,1,1trifluoroethane (CTF), 2-chloro-1,1-difluoroethylene (CDF) formation; oxidation - trifluoroacetic acid (TFAA) formation. The above reactions are shown in Scheme I.

Products from reductive metabolism have more hepatotoxic potential than metabolites produced after oxidation (Ray et al., 1991). Much attention has focused on the role of reductive metabolism in mediating halothane hepatotoxicity. It has been proposed that $\mathrm{CF}_{3} \mathrm{CHCl}$ free radicals are formed by cytochrome $\mathrm{P} 450$. Some of these radicals initiate lipid peroxidation in the endoplasmic reticulum. The damage produced by this process might be responsible ultimately for cell death. 


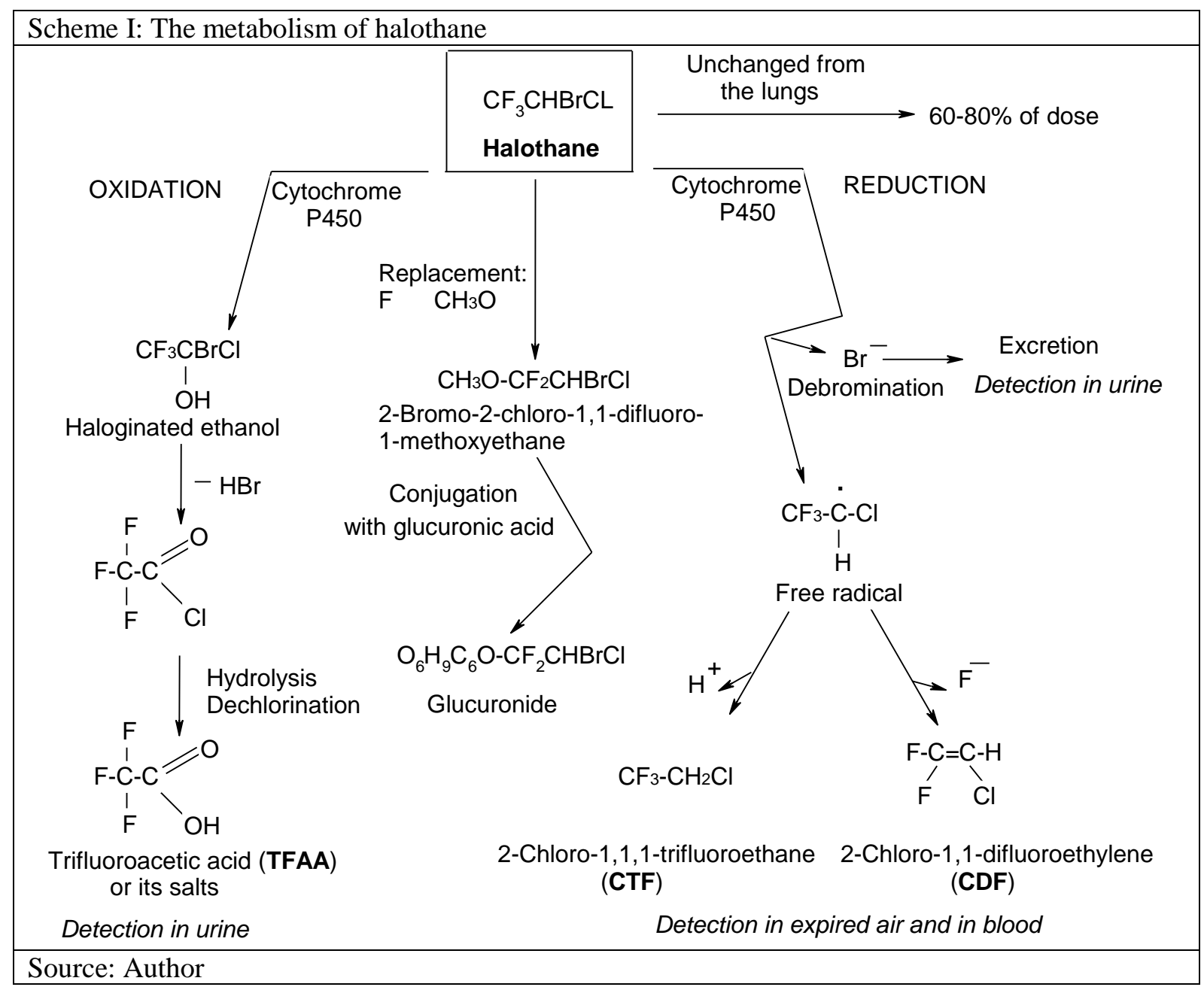

Reactions of fluoride-ions determination are performed after the mineralization with mixture for burn: with calcium chloride solution; with ferric (III) thiocyanate solution; with a solution of alizarin in the presence of zirconium nitrate and $\mathrm{HCl}$ (Scheme II).

Scheme II: Reactions of fluoro-ions determination


Quantitative determination of halothane is performed with the help of instrumental methods of analysis: - chromatographic: gas chromatography $(\boldsymbol{G C} / \boldsymbol{F T I R ,} \boldsymbol{G C}-\boldsymbol{M S})$, High Pressure Liquid Chromatography (HPLC/DAD); - spectral: mass-spectral (MS), infrared spectroscopy (IRFTIR) (Flanagan et al.,2007; Moffat et al., 2011; Saito et al., 1995). Combinations of these methods are used to determine the fatal doses of halothane for some biological objects (Table 1).

Table 1. Fatal doses of halothane for biological objects and methods of their quantification

\begin{tabular}{|c|c|c|}
\hline Biological object & Fatal dose of Halothane & Quantification \\
\hline Blood & $650 \mathrm{mg} / \mathrm{L}$ & $\boldsymbol{G C}, \boldsymbol{G C}-\boldsymbol{M S} \boldsymbol{H} \boldsymbol{H P L C}$ \\
\hline Brain & $1560 \mu \mathrm{g} / \mathrm{g}$ & $\boldsymbol{G C}-\boldsymbol{M S}$ \\
\hline Liver & $880 \mu \mathrm{g} / \mathrm{g}$ & $\boldsymbol{G C}-\boldsymbol{M S}$ \\
\hline Lung & $500 \mu \mathrm{g} / \mathrm{g}$ & $\boldsymbol{G C}-\boldsymbol{M S}$ \\
\hline Spleen & $230 \mu \mathrm{g} / \mathrm{g}$ & $\boldsymbol{G C}, \boldsymbol{G C}-\boldsymbol{M S}, \boldsymbol{H P L C}$ \\
\hline Urine & $20 \mathrm{mg} / \mathrm{L}$ & \\
\hline Source: Author & &
\end{tabular}

\section{Conclusion}

Halothane is a well-known medical preparation that is studied in the discipline «Forensic chemistry» as a «medicinal» poison, which requires from future specialists the carefully study of the methods of qualitative and quantitative determination of this substance not only in medical forms of preparations and in substance, but also in biological objects. We propose a logically consolidated system in the study of this medication, starting its consideration with data of use in medicine, toxicological significance, metabolism, and ending with chemical and physicochemical methods of determination. A modern pharmacist should be armed with a wide range of knowledge about the activity of medications. Deeper knowledge of the possible toxic effects of drugs, and the interaction of drugs and toxic metabolites which are products of «lethal» synthesis, and the symptoms of poisoning with "medicinal" poisons will help prevent poisoning and even the death of the patient.

\section{References}

Bayerman, K. (1987). Opredelenie sledovih kolitcestv organitceskih veschestv [Determination of minimal quantities of organic substances]. (462 p.). Moscow, M.: "Mir". (In Russian).

Busari, J., \& Arnold, A. E. R. (2009). Educating Doctors in the Clinical Workplace: Unraveling the Process of Teaching and Learning in the Medical Resident as Teacher. Journal of Postgraduate Medicine, 55(4), 278-283. doi: 10.4103/00223859.58935

Ellenhorn, M.J. (2003). Medicinskaya toksikologiya: Diagnostika i lechenie otravleniy tcheloveka [Medical toxicology: Diagnosis and treatment of human poisoning] (2-d ed.) (G.K. Faizova, Y.L. Amchenkova, S.B. Matveeva, S.V. Demicheva, Trans.): In 2 vol. Vol.2. (p.203-213). Moscow, M.:"Medicine“. (Original work published 1995). (In Russian).

Erskine, R. \& James, M.F.M. (1990). Isoflurane but not halothane stimulates neutrophil chemotaxis. British Journal of Anaesthesia, 64, 723-727.C European Association for Quality Assurance in Higher Education. Helsinki, 2005.

Flanagan, R. J. et al. (2007). Fundamental of analytical toxicology. (p. 171-204). England: John Wiley \& Sons, Ltd.

Knunyants, I.L. (Ed.) et al.. (1992).). Khimicheskaya enciklopediya [Chemical encyclopedia]: (Vols.1-5). Moscow, Russia: Sov. Encycl. (In Russian).

Komunike Konferencii Ministriv evropeyskih krain, vidpovidalnih za sferu vizhoi osvity [Communiqué of Conference European countries' Ministers which responsible for higher education]. Budapest - Vienna, 12 March 2010.

Moffat, A. C., Osselton, M.D., \& Widdop, B. (2011). Clarke's analysis of drugs and poisons in pharmaceuticals, body fluids and postmortem material (4-th ed.). (p.232-238). UK, USA: Pharmaceutical Press.

Project 562013-EPP-1-2015-1-PL-EPPKA2-CBHE-SP "Quality assurance system in Ukraine: development on the base of ENQA standards and guidelines" Erasmus + Wroclaw, 2015,

Ray, D.C. \& Drummond, G.B. (1991). Halothane hepatitis. British Journal of Anaesthesia, 67, 84-99.

Saito, K. et al. (1995). Determination of the volatile anasthetics halothane, enflurane, isoflurane, and sevoflurane in biological specimens by pulse-heating GC-MS. The Journal of Analitycal Toxicology, 19, 115-119.

Welchinska, E.V. (2017). Toxicological and forensic chemistry (criminal analysis). Poisonous substances and their biotransformation. (p. 53-60). Kiev, Ukraine.: ID “ADEF-Ukraine“.(In English). 